\title{
SECTION 107 OF THE LAND TITLES ACT
}

\section{E. MIRTH, Q.C.}

Section 107 of the Land Titles Act prevents the operation of certain interests in land described in terms of personal property security. The section was amended in 1990 in response to the enactment of the Alberta Personal Property Security Act. This comment examines the historical application of the section and continues on to look at how the amended section will be interpreted. It is concluded that the wording potentially catches more than is needed to secure the section's original purpose.
L'article 107 du Land Titles Act empêche l'application de certains droits immobiliers décrits en termes de garantie mobilière. L'article a été modifié en 1990, suite à l'adoption de l'Alberta Personal Property Security Act. Le présent commentaire examine l'application historique de l'article et étudie ensuite comment l'article modifié sera interprété. II conclut que la formulation dépasse l'objet original de l'article.

\section{TABLE OF CONTENTS}

I. THE PROBLEM $\ldots \ldots \ldots \ldots \ldots \ldots \ldots \ldots \ldots \ldots 6 . \ldots \ldots$

II. BACKGROUND CASE LAW TREATMENT $\ldots \ldots \ldots \ldots \ldots 663$

III. THE 1990 AMENDMENT $\ldots \ldots \ldots \ldots \ldots \ldots \ldots \ldots \ldots \ldots 68$

IV. INTERPRETATION OF THE AMENDMENT $\ldots \ldots \ldots \ldots \ldots 670$

V. CONCLUSION ....................6 672

\section{THE PROBLEM}

Section 107 of the Land Titles Act, R.S.A. 1980, c. L.5 has become the subject of much current debate in light of the enactment of the Personal Property Security Act, S.A. 1988 c. 4.05 (the "PPSA") on October 1,1990 . The section basically negates the operation of a land mortgage, charge or encumbrance contained in what until October 1 , 1990, was described in terms of chattel sales contracts but since October 1, 1990, is described in terms of "purchase money security agreements." The change in terminology came as a consequential amendment in the PPSA (s. 86).

\section{BACKGROUND CASE LAW TREATMENT}

The land titles section is old, going back to 1910 in Alberta. Its original form was described in the early Alberta decision of Nichols \& Shepard Co. v. Skedanuk (1913), 5 W.W.R. 118 (C.A.), at 119 as follows:

"... every mortgage ... upon land ... contained in, endorsed upon or annexed to a written order, contract or agreement for the purchase of a delivery of any chattel or chattels shall be null and void to all intents and purposes whatsoever."

Similar legislation existed since an even earlier date (1893) in Manitoba and its purpose was described in Smith v. American-Abell (1907), 17 Man. L.R. 5 in a passage cited (in part) with approval by Harvey, C.J., in Nichols \& Shepard, at 120 (Smith, supra, at 8-9): 
It was aimed at and framed to suppress a practice which widely prevailed amongst implement dealers of inducing farmers to purchase machinery on credit, taking from them written orders or agreements containing a clause which made the purchase money a charge or lien upon their lands. The intention of the Act was to prevent titles to land from being encumbered by the registration of such documents. It often happened that a farmer, who had paid for his machinery in full, had neglected to obtain a release of lien. When he next came to deal with the land, the lien formed a cloud upon his title, and it was often difficult and expensive to procure the necessary release, when the manufacturers lived in another province or in a foreign country, or had gone out of business. Farmers were often induced to sign such orders or agreements in ignorance of the fact that they were creating liens on their farms. The Act was aimed at suppressing the registration of the documents so as to keep the titles clear.

As the Alberta court went on to add in Nichols \& Shepard, supra, at 120-121:

It seems to me that all the legislature intended was to prohibit a form of taking security which lent itself very easily to, and I might add was often borrowed for the purpose of, the perpetration of a fraud on a purchaser of machinery. A fraud may, of course, be perpetrated in the case of other forms but there appears to be only one form dealt with in the statute. Interfering as it does with the common law rights of contract, its words should certainly not be given to intend that interference beyond what appears to be necessary to give effect to the purpose of the act.

The operation of the provision was accordingly narrowly confined in Alberta, as it had been in the earlier Manitoba decision. It was held:

1. To be directed at the form, not the substance, of the agreement. If the mortgage was contained in a separate free-standing document (free-standing in the sense that "it does not require resort to be made to the written [chattel sales] agreement for any of its terms nor does the written agreement require the mortgage to support it in any way" (Nichols \& Shepard, at 120)) it would not be affected by the section. A mortgage securing a chattel sale price is not per se invalid:

It [the section] contains no suggestion that a mortgage on land may not be taken as security for the purchase price of chattels, but what it does say is that that shall not be done as part of the written agreement for sale.

2. The sales agreement had to be in writing.

3. Despite the wording of the section, the mortgage is not invalidated directly, but rather only its registration and operation of its registration under the Land Titles Act is affected.

(On the third point, see also Barry v. Heider (1914), 19 C.L.R. 97.)

The Court of Appeal's decision in Nichols \& Shepard, supra, appears to have resolved a split in opinion at the Alberta trial court level. Harvey, C.J.'s judgment reversed a decision by Stuart, J. reported in (1913), 4 W.W.R. 587. A contemporaneous trial court ruling by Beck, J., in Perrault v. Rumely Products Co., (1913), 4 W.W.R. 1291 had 
rejected the position of Stuart, J., in Nichols \& Shepard. Mr. Justice Beck said (at 1291-92):

The provision in the order for the giving of the mortgage is undoubtedly void under ch. 5 of 1910 (Alberta) 2nd session entitled 'An Act respecting charges upon land contained in certain Instruments.' The question is, whether the mortgage executed contemporaneously with it but not 'contained in or endorsed upon or annexed to' the order is also void. I am of opinion that it is not so. The obvious purpose of the act to my mind is to put a stop to what had by experience come to be common, namely. the procuring of signatures of persons who were more or less illiterate or uneducated or of little business capacity or careless in the scrutiny of what they signed to long and intricate orders for chattels containing provisions for charges upon the signatories' land by way of security for the purchase price of the chattels because it was always difficult at least, to establish what in many cases there seemed to be a strong suspicion was the truth that the signatory had not in fact given his voluntary and explicit consent to the provision for such security.

The case is different where an entirely distinct and separate document of security is executed and I cannot see that the words of the act cover such a case. Mr. Justice Stuart in Nicols v. Skedanuk (No. 2), 4 W.W.R. 587, seems to have expressed a different opinion but it does not appear to have been necessary for his decision which can very well be supported on other grounds.

Beck, J. clearly viewed the agreement to mortgage land contained in the sales order void, but held that a separate free-standing mortgage doing what was prohibited in the sales order itself would be valid.

The reasoning of Stuart, J., in Nichols \& Shepard, supra (S.C.T.D.), at 595, seems persuasive:

Now the defendant signed an order for machinery of which the purchase price was to be $\$ 5,026.00$ and the agreement or order contained the following clause:

-The purchaser agrees to fully settle for the above described machinery before it is delivered to him by paying said freight and charges by given said notes on the blank forms of the vendor and signing a receipt for the goods received and for the further securing payment of the price of the said machinery and the said notes and all other obligations given therefor and the costs of drawing and registering the mortgage the Purchaser agrees to deliver to the vendor at the time of the delivery of the said machinery as herein provided, or at the option of the Vendor at any time thereafter upon demand a mortgage on the land hereinafter referred to and set over the signature of the Purchaser at the foot hereof in the Statutory form containing also the special covenants and provisions in the mortgages usually taken by the Vendor.'

In the first place I think it is perfectly obvious that that clause in the agreement comes within the wording of the statute and is null and void. I think the clause is a "charge or encumbrance" upon the land mentioned within the meaning of those words.

In Fell v. Official Trustee of Charity Lands (1898) 2 Ch. 44, at p. 54, 67 L.J. Ch. 385, 78 L.T. 474, 62 J.P. 804, Lindley, M.R., said "To draw a distinction between making a charge and doing that which necessarily involves a charge is too subtle. Whether I sign a piece of paper and so create a charge or whether I do an act which creates a charge appears to me to be immaterial as regards this prohibition." In Wharton's Law 
Lexicon encumbrance is defined as "a claim, lien or liability attached to property" and this is quoted with approval by Romer, J., in Jones v. Barnert (1900) I Ch. 370, 69 L.J. Ch. 242, 82 L.T. 32. An agreement to give a mortgage certainly comes within the meaning of these terms. It is, in effect, an equitable mortgage: see Coote on Mortgages, 8 th ed., p. 53. The clause therefore is one plainly struck at and rendered null and void by the statute. Yet the plaintiffs allege that it was in pursuance of that agreement that the separate piece of paper, the real mortgage relief relied upon, was given. Even if there were nothing more in the case I think it would be very much open to doubt whether when an equitable mortgage given in one document is made null and void by statute a concurrent legal mortgage given at the same instant and in pursuance of the other equitable mortgage and to secure the same debt and for the same purpose should not be treated as also null and void.

His Lordship, however, found that the sales agreement and mortgage of land in the case before him were in substance one agreement and hence the mortgage was "contained in" the chattel sales contract. On this he was overruled in the Court of Appeal, which confined the statute to the form, not the substance of the agreement.

\section{Query whether in light of s. 10 of the Interpretation Act:}

10. An enactment shall be construed as being remedial, and shall be given the fair, large and liberal construction and interpretation that best ensures the attainment of its objects.

and in light of extensive modern jurisprudence importing this concept into construction of other statutes (e.g. the Law of Property Act, R.S.A. 1980, c. L-8(i), as viewed in Paramount Life Insurance Co. v. Hilton, (1988) 58 Alta. L.R. (2d) 13 (C.A.) or the Saskatchewan Limitation of Civil Rights Act, R.S.S. 1978 c. L-16, s. 2, as viewed in National Trust v. Mead, [1990] 5 W.W.R. 459); and in light of numerous recent cases viewing similar legislation as bearing on the substance of the transaction rather than its form (e.g. Clayborn Investments Ltd. v. Wiegert (1977), 3 Alta. L.R. (2d) 295 (C.A.); Coop Centre Credit Union Ltd. v. Greba, [1984] 5 W.W.R. 481 (Alta. C.A.)), would Mr. Justice Stuart's views be more likely to persuade today?

Precisely such a treatment came from Matheson, D.C.J., in Re: Le Banque Can. Nat., [1947] 1 W.W.R. 910 (Alta.). Farm machinery was there sold with lien notes being taken for the price. The seller claimed to have a separate signed document agreeing to give the vendor a mortgage collateral to the lien notes. A caveat was filed in respect of such agreement. Judge Matheson, without citing prior case law, said simply (at 911):

In my view, the alleged agreement was "annexed" to the lien notes within the meaning of sec. 103 of the Land Titles Act, R.S.A. 1942, ch. 205, and consequently null and void.

The word "annexed" is capable of a wider meaning than the words "attached" or "affixed," and keeping in mind the purpose and scope of the said sections (as originally enacted by 1910, 2nd sess., ch. 5, An Act respecting Charges upon Land contained in Certain Instruments) should receive a liberal interpretation.

The absence of clear statement of the facts and the absence of authority, however, make this decision unreliable. 
The section has been considered in another more recent Alberta decision: Barker v. Belzberg, (1951) 4 W.W.R. (NS) 304. There Egbert, J. dealt with a land mortgage taken back on the sale of a partnership interest that included personal property (chattels). The land mortgage was a separate instrument. A chattel mortgage was also taken. The sale was made on dissolution of the partnership. The dissolution agreement provided that the remaining (purchasing) partner would grant "as collateral security only" a mortgage on his house "to be deemed to be applied on the said purchase price and interest".

For various reasons, including the principle that sale of a partnership interest is a sale of a chose in action and not a sale of goods or chattels, the Court held that s. 103 (now 107) did not apply.

By the time of this case, the Land Titles section bore substantially the wording it had before October 1, 1990, including the words to the effect that the mortgage, charge or encumbrance "shall be null and void to all intents and purposes whatsoever, notwithstanding anything contained in any Act." Nonetheless, Egbert, J., came to the same conclusion as to the interpretation of the section as the Court of Appeal had in Nichols \& Shepard, supra (although he did not cite that case in his judgment). He said the following (at 312-13):

\footnotetext{
However, it seems to me that for another very apparent reason the plaintiff cannot succeed on this branch of his case. In order that a mortgage, charge or encumbrance upon land be null and void by virtue of sec. 103, it must be 'contained in, endorsed upon or annexed to a writing or instrument written or printed ... required to be registered in order to preserve the rights of the sellor or bailor of goods as against any purchaser or mortgagee of or from the buyer or bailee of the goods,' or it must be 'contained in, endorsed upon or annexed to a written order, contract or agreement for the purchase or delivery of any chattel or chattels.'
}

The land mortgage of April 1, 1949, is not contained in, endorsed upon, or annexed to any other instrument whatsoever. It is a separate instrument containing nothing but the charge upon the land therein described, and I fail to appreciate by what ingenuity of argument it can be contended that it falls within the purview of secs. 103 and 104 of The Land Titles Act. If the agreement of April 1, 1949, were to be considered as an agreement for the purchase or delivery of any chattel or chattels, it might, I suppose, have been argued, with some hope of success, that clause 4 of the agreement whereby the plaintiff agreed to grant a mortgage on the land in itself created an equitable charge on lands and was accordingly null and void by virtue of sec. 103, but that contention was raised neither by the pleadings nor by counsel's argument, the whole basis of the plaintiff's claim being that the separate land mortgage of April 1 was null and void by virtue of sec. 103 . In my opinion, if the transaction took the form it took here and a separate mortgage were contemporaneously or subsequently executed by the mortgagor, such mortgage would be valid and enforceable and not affected by the provisions of sec. 103. The plaintiff must accordingly also fail on the second branch of his action.

One last reference warrants mention: Re: Land Titles Act and Cockshutt Plow Co., [1920] 3 W.W.R. 1069. There Harvey, C.J. was faced with a short agreement to mortgage land clearly containing a reference to security of a debt outside the mortgage. It said: 
For value received and in consideration of receiving an extension of time in which to pay my debt to them, I hereby promise and agree to give Cockshutt Plow Company Limited a mortgage on my land ... as general and continuing security covering my account, with interest as provided therein and I charge my account with them on my land...

Here was a situation significantly different from Nichols \& Shepard, supra, where the Court founded itself on the free-standing nature (absence of cross-reliance) of the land mortgage.

Nonetheless, the Chief Justice found the Land Titles Act provision inapplicable (at 1070-71):

It is suggested that the instrument is objectionable under ch. 5 of the Statutes of Alberta 1910 (2nd sess.), [An Act respecting Charges upon Land contained in Certain Instruments]. It is to be noted, however, that that statute seems to be limited expressly to charges created under an instrument which is commonly known as a lien note. The purpose of the instrument in question here is no doubt to give the same security as is prohibited by that chapter, but there is not the slightest doubt that the security could be given by way of mortgage without objection, and apparently the mischief which the Act is passed to remedy is the danger of a person giving a charge inadvertently when he supposes he is only giving a lien note. I think there is no warrant for extending the provisions of the statute beyond its expressed terms and that a charge created otherwise than as connected with a lien note does not come within the prohibition of the statute.

\section{THE 1990 AMENDMENT}

Section 107 provided, before October 1, 1990, the following:

107(1) A mortgage, charge or encumbrance on land or on any estate or interest therein

(a) contained in, endorsed on or annexed to a writing or instrument that is written or printed, or partly printed, or any part thereof, and that is required to be registered in order to preserve the rights of the seller or bailor of goods as against any purchaser or mortgagee of or from the buyer or bailee of the goods in good faith for valuable consideration, or against judgments under the Conditional Sales Act, or

(b) contained in, endorsed on or annexed to a written order, contract or agreement for the purchase or delivery of any chattel or chattels,

is void to all intents and purposes whatsoever, notwithstanding anything in any Act.

(2) No such mortgage, charge or encumbrance, and no caveat founded thereon, or on any such writing or instrument, shall be registered or filed under this Act.

(3) If any such writing or instrument, in inadvertence, accident or otherwise howsoever, is registered or filed in any Land Titles Office contrary to this section, the registration or filing is ineffective and nugatory to all intents and purposes whatsoever, and may be cancelled by a judge of the Court of Queen's Bench on the application, of any person interested, by originating notice. 
This, apart from restructuring into subparagraphs in the 1980 statute consolidation and a few minor wording changes, is the same provision that Egbert, J., considered in 1951. There is nothing in the case law or any of the statutory revisions since 1951 to suggest that the views of Egbert, J. and Harvey, C.J. are no longer applicable.

That being so, until September 30,1990, there should have been no question that lender financing on the security of both land and chattels should be outside the operation of $\mathbf{s}$. 107 , even as to vendor-take-back financing on the sale of land and chattels. The narrow confinement of the section carried away any real fear of the section. Similarly, the inclusion in land mortgages of some reference to chattels being also secured (e.g. the common inclusion of appliances within the security, whether in the land mortgage or a collateral chattel mortgage or both) would not be a source of concern. (Registration requirements under the Bills of Sale Act, R.S.A. 1980, c. B-5 of course are intentionally excluded from this statement.)

What, then, has s. 86 of the PPSA done to create a fuss? Essentially, it replaces language referable to conditional sales contracts with terminology referable to a broader concept: "purchase money security agreements." The former deals only with vendor positions; the latter addresses both vendor and lender positions. A "purchase money security interest" is defined in the PPSA as:

(ii) 'Purchase-money security interest' means

(i) a security interest taken or reserved in collateral to secure payment of all or part of its purchase price,

(ii) a security interest taken in collateral by a person who gives value for the purpose of enabling the debtor to acquire rights in the collateral, to the extent that the value is applied to acquire those rights,

(iii) the interest of a lessor of goods under a lease for a term of more than 1 year, or

(iv) the interest of a person who delivers goods to another person under a commercial consignment

This renders not only a secured seller of goods the holder of a purchase money security interest, but also a third-party lender who only finances purchase. In that regard, it is different from the "purchase money security interest" in the amended Law of Property Act, which limits itself to interests of sellers of consumer goods.

(f) "purchase-money security interest" means a security interest taken or reserved in consumer goods by a seller to secure payment of all or part of its purchase price and any credit charges payable in respect of the purchase;

The amendment of s. 107 of the Land Titles Act refers to the "purchase money security interest" ("PMSI") as defined in the PPSA. The amendment provides the following: 
(a) in section 106.1, by adding "and the Personal Property Security Act" after "Builders' Lien Act";

(b) in section 107

(i) by repealing subsection (1)(a) and substituting the following:

(a) contained in a purchase-money security agreement that may be registered under the Personal Property Security Act, or

(ii) by adding the following after subsection (3):

(4) In this section, 'purchase-money security agreement' means an agreement that provides for a purchase-money security interest as defined in the Personal Property Security Act.

\section{INTERPRETATION OF THE AMENDMENT}

Because of the broader definition it becomes arguable that any lender who finances land and chattels and takes a common security instrument that includes or may include any personal property acquisition financed by the lender risks the voiding of his land interests!

Is such argument truly a serious risk? From the litigation perspective - what the courts are likely to rule - probably not. From a conveyancing certainty perspective, however, the argument remains a concern.

The amendment in 1990 was clearly intended to be consequential. Terminological reference to the now-repealed Conditional Sales Act needed replacement. Only subsection (a) of section 107 was amended. It is the subsection that expressly referred to contracts requiring registration under the Conditional Sales Act. Subsection (b), which refers generally to chattel purchase contracts, remained in place unchanged. If the amendment in subsection (a) was intended to do more than contemporize the registration statute reference it would have been unnecessary (and indeed undesirable) to retain subsection (b). On the other hand, one might query the need for subsection (a), in light of (b), even before 1990 .

While a better choice of replacement term might have calmed nervous readers of the amended statute, this consequential amendment is not likely to be treated by the courts as having wrought a dramatic change to the purpose and intent - or to the continued probable narrow judicial construction - of section 107. Doing otherwise would be difficult to square with the treatment of a number of statute interpretation rules:

1. The rule in Heydon's Case, (1584) 3 Co. Rep. 7a, 76 E.R. 637, which keys interpretation on the "mischief" which the legislation was originally directed to cure.

2. Continuation of construction applied in prior judicial interpretations if the language has not been materially changed: see Fagnan v. Ure, [1958] S.C.R. 377. (This point begs the issue if one starts with the premise that the purchase money security agreement ("PMSA") reference is a material change in language). 
3. Reference to the legislation's evolution in determining its intent: see Gravel v. City of St. Leonard, [1978] I S.C.R. 660.

4. Presumption against substantial alteration of the law beyond what is explicitly declared: see Nokes v. Lancaster Amalgamated Collieries, [1940] A.C. 1014; see also CMHC v. Wheeler, November 15, 1990, Alberta Court of Appeal, unreported, leave to appeal granted by S.C.C. March 28, 1991 (unreported).

5. By analogy, in respect of consequential amendments, to the rule applied in England to consolidation statutes, that they are strongly presumed not to alter the existing state of the law: see Dreidger, Construction of Statutes (2nd ed.) at 214.

6. Section 29 of the Interpretation Act also may have some bearing on the matter. It contemplates priority of legislation that incorporates over legislation that is incorporated:

29. If an enactment provides that another enactment of Alberta, Canada or another province applies, it applies with the necessary changes and so far as it is applicable. [emphasis added]

See also the same common law concept expressed in Toulbourn Township v. Ottawa-Carleton Reg. Council, (1979) 29 N.R. 267. See also s. 33(2) and (3) of the Interpretation Act, supra.

Indeed, the 1990 amended section is narrower than its predecessors in at least one respect. It confines itself to mortgages, charges and encumbrances "contained in" PMSAs. The words "endorsed or annexed to" were deleted. The mortgage now must be physically in the PMSA itself. If anything, such confinement emphasizes (or at least evidences) an intent to retain the interpretation of Nichols \& Shepard, supra, and Barker v. Belzberg, supra, where the Courts had to wrestle to a degree with the separateness of the mortgage document.

What is perhaps more significant is the fact that the section still uses the terminology "contained in" an agreement. If the section had been changed to say "containing" a PMSI, the possibility of major re-direction would have been more readily identifiable. The prohibition relates to a mortgage of land "contained in" an agreement even after the amendment; and it is difficult to see how it could reasonably be argued that a mortgage of land which contained also some reference to chattel security could be said to be "contained in" a chattel security agreement. Even on Mr. Justice Stuart's view of s. 107's forebear in Nichols \& Shepard, supra, (S.C.T.D.) (revised by the Court of Appeal, supra), if the substance of the transaction were a mortgage the section would not be violated.

Some importance might be placed upon the fact that the Land Titles Act amendment didn't key on the narrower "PMSI" of the Law of Property Act. However, that PMSI is confined to consumer goods. Farm equipment is not (normally) consumer goods. At most, one might say that the Land Titles amendment should have adopted its own definition of PMSI. (Perhaps one might argue with the need for continuation of s. 107 
at all today but that's another matter.) In any event, the failure to use the Law of Property Act PMSI is readily explained.

On the other hand, the fact that the Legislature did not select a special definition for the Land Titles Act is troublesome. Furthermore, literally interpreting the legislation, sans its historical background, it certainly seems to say that the containment of land security in any PMSA renders the land security void. That appearance is a valid cause for concern for any lender or conveyancer acting for a lender who wants an enforceable security agreement beyond doubt, where the personal property aspect of the security agreement arrangement is sufficiently important to raise some reasonable argument that it is the substance of the agreement.

\section{CONCLUSION}

On balance, the issue of the construction to be applied to the "new" s. 107 remains best dealt with by resort to basic principles - the historically-based and purposive narrow construction of the section and the basic rules of statutory construction. Under those principles the "new" s. 107 should not operate significantly more widely than the old one.

However, that is not to say that amendment of the 1990 amendment is not desirable. As long as the present wording potentially catches more than is needed to secure the section's original purpose there will be valid concern over the potential impact of the section. Specific separate definition of the PMSI term in the Land Titles Act (perhaps even re-definition of the PMSA term to confine it to farm equipment sales), or perhaps simple deletion of subsection (1)(a) and (4), is needed to dispel that concern.

In the meantime, it may be prudent for lenders who seek to finance on the security of both land and chattels, and whose finance proceeds may be "purchase money" for personal property to a substantial degree, to keep the security documents distinct and separate as between land security and personal property security. 